\title{
KOMALA BUMI PERTIGA DAN PERANANANYA DALAM PEMERINTAHAN KESULTANAN BIMA TAHUN 1747-1751
}

\author{
Ilmiawan \\ Prodi Sejarah, FKIP Universitas Muhammadiyah Mataram \\ awanilmi106@gmail.com
}

\section{INFO ARTIKEL}

Riwayat Artikel:

Diterima: 04- 04 - 2018

Disetujui: 12- 07- 2018

\section{Kata Kunci:}

Komala bumi pertiga Kesultanan Bima

\section{A. LATAR BELAKANG}

Bangsa yang arif dan bijaksana, akan selalu mempelajari dan memahami sejarah bangsanya untuk dijadikan cermin kehidupan hari ini dan hari yang akan datang. Sejarah selalu memperingatkan kepada kita betapa besarnya bahaya yang akan menimpa kehidupan manusia, apabila manusia melupakan dan menghianati sejarah. Bangsa yang hidup di masa silam mengalami

\begin{abstract}
Abstrak: Penelitian ini bertujuan untuk mengetahui bagaimana Peranan Komala Bumi Pertiga pada Pemerintahan Kesultanan Bima Tahun 1747-1751 dan untuk mengetahui upaya-upaya yang ditempuh pada masa pemerintahannya Untuk mengetahui Faktor-faktor apa sajakah yang menandai keberhasilan Komala Bumi Pertiga dalam menjalankan kesultanan Bima tahun. Metode yang digunakan dalam penelitian ini adalah Kualitatif Deskriptif. Berdasarkan hasil observasi dan wawancara dilapangan dapat disimpulkan bahwa Peranan Komala Bumi Pertiga, seorang wanita berdarah Bima-Makassar, yakni anak dari Sultan Bima Alauddin Muhammad Syah dengan permaisurinya Karaeng Tana Sanga Mamuncaragi, putri Raja Gowa yang bernama Sirajuddin. Pada masa pemerintahan kesultanan Bima dikemudi dan dijalankan oleh Komala Bumi Pertiga yang didampingi oleh wali Sultan Ruma Bicara Abdul Ali, Komala cukup memberikan hak dan peluang kepada masyarakat (rakyat) untuk menyalurkan aspirasi terhadap perkembangan demi perkembangan yang terjadi di dalam kesultanan bima dan sama-sama menghadapi kondisi Belanda yang ingin menjalankan politik monopoli di samping mengadu domba antara pemerintahan kesultanan Bima dengan Makassar tentang daerah Manggarai yang sudah dijadikan mahar dalam perkawinan antara Sultan Alauddin Muhammad Syah dengan Karaeng Tana Sanga Mamuncaragi. Dengan menelusuri jejak perjuangan dan peranan Komala Bumi Pertiga dalam pemerintahan, baik di saat didampingi oleh wali Sultan Ruma Bicara Abdul Ali maupun di masa adiknya Abd. Kadim menginjak usia cukup dewasa, mengambil kembali tampuk pemerintahan, peranan beliau cukup nampak terlihat dan akan diingat selalu oleh zaman yang merasakan dan menikmati daerah Bima yang sudah bebas dan merdeka ini. Kisah perjalanan hidup sampai wafatnya Komala Bumi Pertiga berperan dalam kancah politik pemerintahan kesultanan Bima. Selama adiknya masih berusia muda, beliau berhasil menyelamatkan Bima dari ancaman Belanda.Usaha yang dilakukannya antara lain: (a) Di bidang Agama, beliau mengutus dan mengirim Mubaligh untuk menyiarkan agama Islam disetiap daerah yang ditaklukan kesultanan Bima, (b) Bidang Pemerintahan, Komala Bumi Pertiga mampu menggagalkan Belanda yang ingin menguasai

daerah Manggarai NTT dan menjalankan monopoli perdagangan di daerah Bima.
\end{abstract}

kejayaan dan mencapai puncak peradaban yang tinggi, karena mereka selalu berguru kepada sejarah. Sebaliknya mereka akan mengalami pengunduran bahkan kehancuran apabila mereka melupakan dan menghianati sejarah. Sebagai langkah awal untuk menyelamatkan kehidupan bangsa pada umumnya khususnya kehidupan masyarakat Bima, sebagai akibat dari sifat yang melupakan dan menghianati sejarah, 
maka penulis ingin menelusuri jejak sejarah Bima melalui karya ilmiah ini. Sebagai darma bakti diri terhadap bangsa dan negara, semoga kelak mendapat perhatian yang serius dari kalangan masyarakat ilmiah dan generasi muda sebagai pelanjut pembangunan daerah. Demikian pula halnya pembangunan nasional akan berjalan dengan mulus dan berhasil dengan baik, apabila setiap daerah ikut berperan aktif dalam pembangunan nasional. Salah satu syarat untuk melakukan pembangunan adalah mereka harus mengetahui latar belakang sejarah kehidupan masyarakat di daerah itu sendiri. Putra - putri Indonesia yang berpredikat orang Bima harus mematuhi secara jujur bahwa sampai saat ini masih banyak anggota masyarakat terutama generasi mudanya yang belum mengetahui secara utuh mengenai sejarah Bima, akibatnya mereka sering kehilangan pedoman dalam melakukan hidup dan kehidupan. Paling menyedihkan ialah masih adanya orang yang beranggapan bahwa mempelajari sejarah pada hakekatnya sama saja dengan usaha menghidupkan feodalisme dan absolutisme. Mereka menyangka para Sultan, pemimpin dan para peranan dalam pemerintah kesultanan adalah merupakan tokoh-tokoh feodalistis yang memerintah secara absolut hanya duduk berpangku tangan di Singgasana Kesultanan, tanpa memperhatikan keadaan masyarakat di daerahnya. Untuk menghilangkan akibat yang merugikan kepentingan masyarakat Bima pada khususnya dan kepentingan bangsa pada umumnya, melalui penelitian ini Penulis mencoba menulis tentang peranan seorang wanita bernama Komala Bumi Pertiga dalam pemerintahan kesultanan Bima pada tahun 1747 - 1751. Peranan beliau dalam pemerintahan kesultanan Bima pada khususnya dan pada bangsa Indonesia pada umumnya, di samping itu penonjolan seorang wanita untuk ikut berperan dan memimpin kesultanan, merupakan sesuatu yang cukup menarik untuk diangkat ke permukaan yang merupakan dapat dihitung dengan jari dinamika ketenaran, keberanian dan kepahlawanan seorang wanita di jaman dahulu menentang penjajahan demi memikirkan kemerdekaan dan nasib generasi anak cucu yang akan datang, namun dalam penelitian ini peneliti akan menelusuri sebagai kepatuhan di mana seorang wanita mampu menangani Kesultanan walau banyak tantangan, hambatan yang datang terutama mengusir penjajah Belanda di wilayah persada Dana Mbojo.

Mengenai sejarah peranan, perjuangan dan pergerakan wanita Bima sangat sedikit kita baca dalam buku - buku sejarah, mungkin karena yang menulis sejarah terdiri dari kaum laki - laki, umumnya yang ditulis juga tentang peranan, perjuangan dan pergerakan laki-laki. Pada kesempatan yang sederhana ini pun peneliti mencoba menguraikan dan memaparkan dengan teliti tentang peranan srikandi Bima Komala Bumi Pertiga dalam Pemerintahan Kesultanan Bima pada tahun $1747-1751$ ketika itu.

\section{B. METODE PENELITIAN}

\section{Jenis Penelitian}

Adapun jenis penelitian yang dipilih dalam penelitian ini adalah penelitian kualitatif dengan pendekatan deskriptif. Disebut penelitian deskriptif adalah penelitian yang dilakukan terhadap variabel mandiri, yaitu tanpa membuat perbandingan atau menghubungkan dengan variabel lain (Moleong, 1998:21). Suatu penelitian yang berusaha menjawab pertanyaan seperti yang tengah diteliti yaitu: "Komala Bumi Pertiga Dan Peranananya Dalam Pemerintahan Kesultanan Bima Tahun 1747-1751"

\section{Jenis dan sumber data}

a. Jenis Data

Secara teoritis, Jenis data kualitatif adalah jenis data yang berhubungan dengan data yang bukan statistik/angka misalnya hasil wawancara, temuan dilapangan dan sebagainya, atau lebih ke aspek validitas, (Sugiyono, 2014: 365).

b. Sumber Data

Sumber data dalam penelitian ini adalah subjek dari mana data diperoleh. Sumber data menurut sifatnya digolongkan menjadi 2 (dua) yaitu sumber data primer dan sumber data sekunder.

1) Sumber data primer adalah sumber-sumber yang memberikan data langsung dari tangan pertama.

2) Sumber data sekunder adalah sumber mengutip dari sumber lain (Sugiyono, 2014:308)

\section{Teknik pengumpulan data}

Teknik pengumpulan data merupakan langkah yang paling utama dalam penelitian, karena tujuan utama dari penelitian adalah untuk mendapatkan data. Tanpa mengetahui teknik pengumpulan data, maka peneliti tidak akan mendapatkan data yang memenuhi standar data yang ditetapkan.

Dalam penelitian ini mengumpulkan data yang berkaitan dengan judul penelitian yang akan dilaksanakan, penulis menggunakan tekhnik wawancara (interview), observasi, dokumentasi.

a. Wawancara

Wawancara merupakan salah satu jenis pengumpulan data dengan melakukan sebuah timbal balik atau dalam kata lain merupakan sebuah percakapan dengan maksud tertentu. Yang dilakukan oleh dua pihak, yaitu pewawancara, yang mengajukan dan terwawancarai (interview) yang memberikan ja waban atas pertanyaan \ itu, (Sugiyono 2014: 309). Sedangkan (Nasution, 1991: 31), wawancara adalah suatu cara yang merupakan pertemuan dua orang untuk bertukar informasi dan ide melalui tanya jawab, sehingga dapat dikontruksikan makna dalam suatu topik tertentu.

b. Observasi

Pengumpulan data untuk suatu tulisan ilmiah dapat dilakukan salah satunya adalah melalui observasi. Pengguna metode observasi menurut 
(Moleong, 1998: 62) adalah pengamatan langsung dari suatu obyek yang akan diteliti, dapat dilakukan dengan waktu yang singkat. Dalam hal ini bertujuan untuk mendapatkan gambaran yang tepat mengenai obyek penelitian sehingga dapat disusun daftar kuesioner yang tepat atau dapat menyusun suatu desain penelitian yang cermat, dan mengecek sendiri sampai dimana keabsahan data dan informasi yang telah dikumpulkan oleh peneliti.

c. Dokumentasi

Dokumetasi sudah lama digunakan dalam sebuah penelitian sebagai sumber data yang dimanfaatkan untuk menguji, menganalisa, menafsirkan, bahkan bisa juga meramalkan setiap bahan tertulis ataupun film (Sugiyono, 2014: 308). Supaya hasil dokumentasi dapat terekam dengan baik, dan peneliti memiliki bukti telah melakukan dokumentasi kepada informan atau sumber data, maka diperlukan bantuan alat-alat sebagai berikut:

1) Buku catatan: berfungsi untuk mencatat semua percakapan dengan sember data. Sekarang sudah banyak computer yang kecil, notebook yang dapat digunakan untuk membantu mencatat dan untuk mengambil data hasil dokumentasi.

2) Tape recorder (Alat Perekam): berfungsi untuk merekam semua percakapan atau pembicaraan. Penggunaan tap recorder dalam dokumentasi perlu memberi tahu kenapa informan apakah dibolehkan atau tidak.

3) Camera: untuk memotret kalau peneliti sedang melakukan pembicaraan dengan informan/sumber data. Dengan adanya foto ini, maka dapat meningkatkan keabsahan peneliti akan lebih terjamin, karen peneliti benarbenar melakukan pengumpulan data atau sumber yang diteliti.

\section{Analisis Data}

Analisis data merupakan proses mencari dan menyusun secara sistimatis data yang diperoleh dari hasil wawancara, catatan lapangan, dan bahan-bahan lain, sehingga dapat mudah difahami, dan temuannya dapat di informasikan kepada orang lain. Analisis data dilakukan dengan mengorganisasikan data, menjabarkannya kedalam unit-unit, melakukan suatu menyusun kedalam pola, memilih mana yang penting dan yang akan dipelajari, dan membuat kesimpulan yang dapat diceritakan kepada orang lain. upaya pengolahan data atau penafsiran data merupakan rangkaian penelaahan, pengelompokan, sistimatisasi dan verifikasi data agar data yang terkumpul bernilai ilmiah (Matthew. B \& Hubermen, 2009: 334).

\section{HASIL DAN PEMBAHASAN}

\section{Peranannya Dalam Menjalankan Roda Kesultanan Bima}

Menurut Hilir Ismail menjelaskan bahwa pada abad $17 \mathrm{M}$ tampil beberapa pejuang wanita Bima yang dengan gigih melawan penjajah Belanda, seperti antara lain Karaeng Bonto Je'ne, Komala Bumi Pertiga. Pada awal abad ke 20 M tampil pula srikandi yang dengan gagah berani maju ke medan laga dengan persenjataan Lira melawan Belanda. Seperti antara lain, Dua Dau dan Dua Masu.

Bagaimana wujud perjuangan dan peranan wanita Bima, terutama peranan Komala Bumi Pertiga di masa lalu adalah amat ditentukan oleh pandangan hidup yang sesuai dengan sistem politik dan pemerintahan, agama dan sosial budaya pada zamannya. Wujud peranan wanita Bima baik dalam melawan penjajah maupun dalam mempertahankan kemerdekaan, mungkin akan berbeda dengan cara yang dilakukan oleh kaum wanita di daerah lain, namun tujuan yang akan dicapai adalah sama. Seluruh wanita Indonesia ingin membela kemerdekaan hak dan harga diri demi terwujudnya negara Indonesia merdeka yang berdaulat.

Pada masa pemerintahan kesultanan Bima dikemudi dan dijalankan oleh Komala Bumi Pertiga dan didampingi oleh wali Sultan Ruma Bicara Abdul Ali, Komala cukup memberikan hak dan peluang kepada masyarakat (rakyat) untuk menyalurkan aspirasi terhadap perkembangan demi perkembangan yang terjadi di dalam sama-sama menghadapi kondisi Belanda yang ingin menjalankan politik monopoli di samping mengadu domba antara pemerintahan kesultanan Bima dengan Makassar tentang daerah Manggarai yang sudah dijadikan mahar dalam perkawinan antara Sultan Alauddin Muhammad Syah dengan Karaeng Tana Sanga Mamuncaragi.

Dengan menelusuri jejal perjuangan dan peranan Komala Bumi Pertiga dalam pemerintahan, baik di saat didampingi oleh wali Sultan Ruma Bicara Abdul Ali maupun di masa adiknya Abd. Kadim menginjak usia cukup dewasa, mengambil kembali tampuk pemerintahan, peranan beliau cukup nampak terlihat dan akan diingat selalu oleh zaman yang merasakan dan menikmati daerah Bima yang sudah bebas dan merdeka ini. Kisah perjalanan hidup sampai wafatnya Komala Bumi Pertiga berperan dalam kancah politik pemerintahan kesultanan Bima, penulis akan mencoba menguraikan kilasan panjang lebar di bawah ini.

\section{Usahanya Dalam Bidang Agama.}

Dalam menjalankan kekuasaannya, pemerintah adalah amanat Allah, yang harus diserahkan dan diusahakan penanganannya kepada orang-orang yang takut kepada Allah, bersifat adil dan benabenar beriman kepadaNya. Setiap Sultan atau Raja didalam memimpin dan perannya didalam kesultanan sudah barang tentu ada usaha dan target yang diharapkan, demikian pula halnya kesultanan Bima dibawah peranan Komala Bumi Pertiga. Dalam 
hal ini beradaskan wawancara dengan bapak Abdul. Gani, bahwa usaha Komala Bumi Pertiga dibidang agama adalah membantu Bimadalam usaha penyiaran agama diwilayah Nusa Tenggara Timur, beliau bersama suaminya Abdul Kudus mengirimkan para ulama dan pedagang Makassar ke daerah daerah taklukan Bima. jelaslah bahwa usaha Komala Bumi Pertiga dalam pemerintahan Kesultanan Bima khususnya dibidang agama cukup berhasil, dimana dalam kondisi yang cukup sulit dan kondisi yang tidak terlalu memungkinkan beliau masih sempat dan sanggup mengekspos (mengutus dan mengirim) para muballiqh untuk menyiarkan agama Islam ke daerah - daerah yang telah ditaklukan oleh Bima.

Suatu hal yang wajar dan logis kiranya bila masyarakat dapat menghormatidan perhatian yang besar terhadap jasa - jasa yang ditinggalkannya sesuai dengan pengalaman dan kemampuan sebagai seorang wanita, dan pantas pual mendapat gelar dimasa itu dengan sebutan Bumi Pertiga. Sehingga terlihat dengan jelas dari hasil nukilan sejarah kemajuan dan perkembangan Islam didaerah Bima baik dimasa peranan sebagai Bumi Pertiga lebih lebih dengan adanya potret Islam di Kabupaten Bima hingga saat sekarang, ini semua tidak lain adalah jerih payah dan usahanya.

\section{Faktor-Faktor Keberhasilan KomalaBumi Pertiga Dalam Menangani Kesultanan Bima}

Keberhasilan Komala Bumi Pertiga dalam menangani dan menjalankan roda kesultanan Bima, berdasarkan wawancara dengan H. Abd. Muthalib adalah sebagai berikut :

a. Dimana Abdul Kadim sebagai Jena Teke (Putra Mahkota) yang berhak menyandang, menaiki dan menduduki tahta kesultanan masih sangat muda, disamping untuk sementara waktu menduduki atau menjabat sebagai Jeneli atau Camat Sape.

b. Ruma Bicara Abdul Ali selaku sebagai Sultan terlalu banyak menjabat, merangkap jabatan, disamping sebagai wali Sultan dan Perdana Menteri (Penasehat Sultan), juga bertugas sebagai Jeneli RasanaE, sehingga dalam menjalankan roda kesultanan sukar baginya menjalankan dengan baik.

c. Komala Bumi Pertiga, adalah turunan Sultan (anak kandumng Sultan), beliau juga memiliki watak dan perangai kesatria, kecerdasan yang juga banyak mengunyak asam garam dari ayahandanya Sultan Alauddin Muhammad Syah, beliau juga memiliki watak politikus sebagaimana halnya dengan kakek beliau Sultan Hasanuddin.

d. Adanya kecintaan masyarakat Dana Mbojo disisi lain, namun suatu ketentuan yang ketat yang merupakan sudah menjadi ketetapan hukum Syara sebelumnya bahwa seorang wanita tidak dapat bertindak sebagai Imam didalam melakukan sembahyang berjamaah. Disinilah letak posisi pengecualian pada diri Komala Bumi Pertiga, namun bukan suatu halangan dan rintangan, terhadap ketentuan hukum Syara tersebut untuk dapat memegang peranan dalam pemerintahan kesultanan Bima

Dengan melihat hasil pendapat tersebut bahwa Komala Bumi Pertiga memiliki kedudukan dan posisi yang dalam mencelupkan suatu karya dan pengalaman dalam pemerintahan kesultanan Bima, namun satu satunya merupakan pengecualian yang bukan menjadi halangan guna memegang peranan adalah wanita tidak dapat memimpin sebagai Imam dalam sembahyang berjamaah. Disisi lain yang merupakan tidak kurang pentingnya, bahwa keberhasilan yang telah dicapai oleh Komala Bumi Pertiga selama memegang peranan dalam tahta kesultanan Bima adalah sebagai berikut :

a. Dapat menggagalkan usaha Belanda yang ingin menguasai Manggarai.

b. Dapat menggagalkan Belanda yang ingin menjalankan monopoli dagang di tanah Bima.

\section{SIMPULAN DAN SARAN}

Berdasarkan hasil penelitian diatas dapat disimpulkan bahwa :

\section{Peranan Komala Bumi Pertiga}

Seorang wanita berdarah Bima-Makassar, yakni anak dari Sultan Bima Alauddin Muhammad Syah dengan permaisurinya Karaeng Tana Sanga Mamuncaragi, putri Raja Gowa yang bernama Sirajuddin. Pada masa pemerintahan kesultanan Bima dikemudi dan dijalankan oleh Komala Bumi Pertiga yang didampingi oleh wali Sultan Ruma Bicara Abdul Ali, Komala cukup memberikan hak dan peluang kepada masyarakat (rakyat) untuk menyalurkan aspirasi terhadap perkembangan demi perkembangan yang terjadi di dalam kesultanan bima dan sama-sama menghadapi kondisi Belanda yang ingin menjalankan politik monopoli di samping mengadu domba antara pemerintahan kesultanan Bima dengan Makassar tentang daerah Manggarai yang sudah dijadikan mahar dalam perkawinan antara Sultan Alauddin Muhammad Syah dengan Karaeng Tana Sanga Mamuncaragi. Dengan menelusuri jejak perjuangan dan peranan Komala Bumi Pertiga dalam pemerintahan, baik di saat didampingi oleh wali Sultan Ruma Bicara Abdul Ali maupun di masa adiknya Abd. Kadim menginjak usia cukup dewasa, mengambil kembali tampuk pemerintahan, peranan beliau cukup nampak terlihat dan akan diingat selalu oleh zaman yang merasakan dan menikmati daerah Bima yang sudah bebas dan merdeka ini. Kisah perjalanan hidup sampai wafatnya Komala Bumi Pertiga berperan dalam kancah politik pemerintahan kesultanan Bima. Selama adiknya masih berusia muda, beliau berhasil menyelamatkan Bima dari ancaman Belanda. 


\section{Usaha - usaha yang dilakukannya antara lain :}

a. Di bidang agama, beliau mengutus dan mengirim muballigh untuk menyiarkan agama Islam ditiap-tiap daerah taklukan Bima.

b. Di bidang kepemerintahan, disamping dapat menggagalkan Balanda yang ingin menguasai Manggarai, juga menggagalkan Belanda yang ingin menjalankan monopoli perdagangan di daerah Bima.

\section{Faktor keberhasilannya antara lain :}

a. Mampu menggagalkan usaha Belanda yang ingin menguasai daerah Manggarai.

b. Dapat menggagalkan Belanda yang ingin menjalankan monopoli perdagangan di daerah Bima.

\section{DAFTAR RUJUKAN}

[1] Abdullah, Ahmad, 1992. Kerajaan Bima dan keberadaannya, Bima : Yayasan Paguyuban La Mbila.

[2] Abdullah Tajib, BA. 1995. Sejarah Bima Dana Mbojo. PT Harapan Masa (PGRI)

[3] Alan Malingi dan M. Hilir Ismail. 2010. Sejarah Kesultana Bima Dompu. Mataram: Mahani Persada.

[4] Amin, Ahmad. Sejarah Bima dan Sejarah Pemerintahan Serba-Serbi Kebudayaan Bima, Terbit : Maret 1982.

[5] Abdullah, Tayeb, BA. Peranan Agama Islam Terhadap Kehidupan Sosial Budaya Bima Terbit : 1982 di Bima tahun 1982.

[6] Al-Banna, Hasan. Majmu'ah, Diterjemahkan oleh Su'adi Sa'adi dengan judul "Konsep Pembaharuan Masyarakat Islam" Cet. I, Jakarta, Media Dakwah, 1987.

[7] BO. Dana Mbojo. (Catatan Lama Istana Bima), Bo Sangaji, BO. Bicarakai, BO. Melayu, BO. Bumi Luma, t.t.

[8] BO (Suatu Himpunan Catatan Kuno Daerah Bima), Oleh proyek Pengembangan Permuseuman : Nusa Tenggara Barat, t.t.)

[9] Cahambert-Loir, Henri, 1982. Sumber melayu sejarah Bima, dalam citra masyarakat Indonesia , Jakarta : Sinar Harapan.

[10] 1985. Syair Kerajaan Bima (Naskah dan dokumen nusantara III), Jakarta-Bandung : EFEO-

[11] Chambert-Loir, Henri dan Maryam R. Salahuddin, 2000. Bo Sangaji Kai Catatan Kerajaan Bima, Jakarta : Yayasan Obor Indonesia.EFEO.

[12] Wejarah Daerah Nusa Tenggara Barat, Pusat Penelitian Sejarah dan Budaya Proyek Penelitian dan Pencatatan Kebudayaan Daerah. 1977/78.

[13] $\longrightarrow$ Sejarah Sekitar Kerajaan Dompu, Terbit : 1985, Dompu,.1985.

[14] Departemen Agama RI. Al Qur'an dan Terjemahannya, Jakarta, YPPA, 1990.

[15] Djamaluddin, Acep. Drs. at. al. Album Seni Budaya Nusa Tenggara Barat, Proyek Media Kebudayaan Departemen Pendidikan dan Kebudayaan. Jakarta : 1977.

[16] M. Hilir, Ismail. Drs. Peranan Kesultanan Bima Dalam Perjalanan Nusantara,Terbit 1988, Bima. 1988.

[17] Miles, Matthew. B \& Hubermen, A Michael. 2009. Analisis Data Kualitatif. UI Pres

[18] Moleong, Lexy J. 1998. Metodologi Penelitian Kualitatif. Bandung Remaja Rosdakarya

[19] Notosusanto, Nugroho, et.al. Sejarah Nasional Indonesia, Jilid : II dan III, Jakarta : 1975.

[20]Nasution, S. Prof. Dr. MA. Metode Research. Edisi Ketiga, Bandung : Jenmars ; 1991.
[21] Rais, M, Amin, Dr., Cakrawala Islam antara Cita dan Fakta, Cet. I, Bandung, Mizan, 1987.

[22] Sutopo, H.B.2006. Metode Penelitian Kualitatif. UNS Press.

[23] Sugiyono. 2014. Metode Penelitian Kuantitatif Kualitatif dan R\&D. Bandung: Alfabeta. 